\title{
Natural Gas Consumption and Economic Growth in Tanzania
}

\author{
Daniel Makala ${ }^{1 \star}$, Li Zongmin ${ }^{1}$
}

${ }^{1}$ Department of Computer Science, China University of Petroleum (East China), Qingdao 266580, CHINA

*Corresponding Author: daniel.makala@outlook.com

Citation: Makala, D., \& Zongmin, L. (2020). Natural Gas Consumption and Economic Growth in Tanzania. European Journal of Sustainable Development Research, 4(2), em0113. https://doi.org/10.29333/ejosdr/6430

\section{ARTICLE INFO}

Received: 29 Jul. 2019

Revised: 18 Nov. 2019

Accepted: 5 Dec. 2019

\begin{abstract}
After crude oil, natural gas has become one of the most important energy sources in the world. For a long time, Tanzania has been exploring for natural gas. The first gas discovering was in 1974 in Songo Songo island southern part of Tanzania and the production started in 2004. It is always believed that gas consumption leads to the growth and development in the economics of that area. The uses of gas in homes, industries increase the living standard of the people. This study concentrates on finding the relationship between natural gas consumption and economic growth in Tanzania by using autoregressive distributed lag model, with the data from TPDC, and World Bank from 1995 to 2018. Economic growth is mainly determined by GDP, FDI, increase of population in the urban and inflation rate. The result of this study indicates that there is no long-run relationship between gas consumption and economic growth. On top of that, causality is only found in Gas consumption to FDI.
\end{abstract}

Keywords: energy, Tanzania, economy, natural gas, ARDL

\author{
Nomenclature \\ $\mathrm{TCF}=$ Trillion Cubic Feet \\ $\mathrm{GDP}=$ Gross Domestic Product \\ FDI = Foreign Direct Investment \\ TPDC $=$ Tanzania Petroleum Development Company \\ BKWH = Billion Kilo Watt Hours \\ ARDL = Autoregressive Distributed Lag
}

\section{INTRODUCTION}

Energy is one of the elements that run the world. For many years the world has depended on oil as the main source of energy. Nevertheless, in recent years the gas has become more attractive in replacing oil as a core source of energy. Energy is important in the process of economic growth and it cannot be underestimated (Hassan, Tahir, Wajid, \& Mahmood, 2017). The need for using natural gas has been rising especially since the year 2000 in the world. Natural gas is mentioned to be a replacement of the oil as the source of energy in the future near. More to that natural gas has become a very attractive source of energy as it has more advantages compared to coal and oil, as it is environmental friendly because of less carbon dioxide ( $\left.\mathrm{CO}_{2}\right)$ produced compare with the popular oil and coal. It also has fewer pollutants (Shahbaz, Arouri, \& Teulon, 2014). All these advantages make many countries to be attracted to use natural gas as a source of energy (Apergis \& Payne, 2010).

In addition to that, Natural gas has been used in different many ways. Apart from being mostly used in the production of electric power, it is also used in cooking, heating, vehicle and producing of fertilizers among others. A higher energy consumption country will have a higher economic growth impact on a nation. According to Kahyoza, he said that Consumption of energy is reflected in overall economic development, being proportional to the growth of GDPs of nations (Kahyoza, 2013), thus this study is aimed to examine the relationship between the natural gas consumption in Tanzania and economic growth.

There is a myth that says oil consumption has a relationship with economic growth. This relation can be direct or indirect. (He \& Gao, 2017) build a model to estimate the relationship between gas consumption and metropolitan economic performance. Their empirical results indicate that there is granger causality from GDP to gas consumption for the long run in Guangzhou china.

Sankaran, Kumar, K, and Das (2019) investigate on the effect of electricity consumption, per capital income, real exchange rate, import and export of manufacturing output for a period of $1980-2016$ in china.using ARDL and ECM, their study results demonstrate the existence of short-run and long-run relationship among the variables. 
Table 1. Trend of Gas consumption and Economic variables from 2004 to 2018

\begin{tabular}{cccccccccccccc}
\hline Year & $\mathbf{2 0 0 4}$ & $\mathbf{2 0 0 6}$ & $\mathbf{2 0 0 8}$ & $\mathbf{2 0 1 0}$ & $\mathbf{2 0 1 2}$ & $\mathbf{2 0 1 4}$ & $\mathbf{2 0 1 6}$ & $\mathbf{2 0 1 7}$ & $\mathbf{2 0 1 8}$ \\
\hline GC & 9.80 & 16.76 & 22.65 & 29.37 & 38.92 & 35.68 & 31.31 & 29.22 & 30.68 \\
\hline GDP & 7.8 & 6.7 & 7.4 & 7.0 & 6.9 & 7.2 & 7.1 & 7.0 & 13.9 \\
\hline FDI & 400 & 400 & 1300 & 1800 & 1900 & 2100 & 1360 & 1200 \\
\hline Inflation & 4.14 & 7.25 & 10.28 & 7.19 & 16.00 & 6.13 & 5.17 & 5.32 & 3.51 \\
\hline Population & 37.38 & 39.55 & 41.85 & 44.97 & 44.93 & 47.42 & 50.14 & 52.55 & 54.20 \\
\hline
\end{tabular}

Because of that this study focus on determining the relationship exist between gas consumption and economic growth in Tanzania. The movement of gas consumption and economic indicator can be summarized in Table 1, from 2004 to 2018.

All the natural gas produced in Tanzania is consumed within the country. Since the commerce of production, consumption has been increasing each year. This increase in gas consumption has been highly contributed by the Electric power generation by using natural gas. Nonetheless, the increase of modern vehicles that use natural gas and industries that operate on natural gas has also contributed to the increase in natural gas consumption. Recent Tanzania has established a project of supplying natural gas in the houses. This project will encourage householders to use the gas in cooking and heating as the main source.

On the other side of economic growth, Tanzania has been doing well in promoting economic growth. According to the African Development Bank report (African Development Bank Group, 2019), Tanzania GDP growth is among the top ten countries with the best growth of about GDP growth of 6.7. From year 2001, Tanzania's GDP growth has been stable between $6 \%$ and $7 \%$.

FDI is one of the economic growth indicators as it shows investment done by individual or company to another country. Tanzania is the best country as she receives more FDI across East Africa. FDI inflow rose by $13 \%$ from 2010 to 2014 , and this was highly contributed by the natural gas discoveries across the country. In 2015, FDI decreased, similar to the following year of 2017.

Price instability in Tanzania has been seen for the past years, but since 2016 the government has aiming reduction of inflation rate. In year 2018, the inflation rate has and reach 3.51\%. Stability of the price in the country implies a stable and reliable economic.

The population in Tanzania has never stopped growing since independence. Current the population is estimated to be $56 \mathrm{mil}$ people. The issue of how the population relates to economic growth is still a controversial issue (Peterson, 2017). The effect of the population in economic growth can be a positive one or negative depending on the situation someone is looking.

\section{REVIEW OF LITERATURE}

This study examines the relationship between natural gas consumption and economic growth. Several studies have been conducted in different countries about determining the relationship between natural gas consumption and economic growth. Similar to gas consumption, other studies focus on energy consumption causality with economic growth.

Moreover, many people believe that any country with a high rich in natural resources such as oil must have a very well developed and better economy. This belief indicates that natural resource has a positive effect on development (Rosser, 2006).

Al-khawaldeh and Al-qudah (2018) uses data from the Central Bank of Jordan and the ministry of mineral resources of Jordan and world bank, for the period of 1992 to 2016 in examining the effect of energy consumption (electric and oil energy) on economic growth in Jordan. Applying multiple regression models, the study's results indicate that energy consumption, in general, has significant positive effects. An increase of $1 \%$ in electric power increases the economic by 1.87069 . Also, $1 \%$ increase in oil consumption causes the economy to grow by $1.96985 \%$.

According to Akinlo, the Nigerian economy is mainly driven by oil production. The huge revenue from oil provides the opportunity to increase expenditure and investments in Nigeria thus increase the opportunity for a job for the local and that accelerates the economy of Nigeria (Akinlo, 2012).

More about enenergy and economic growth, for any country that has low price energy, it will increase production as well as investments in small industries and heavy industries, thus push more in the production of goods and services and push further the economic growth of that country. This explains the role of the revolution have been constrained by economic growth due to the development of coal consumption methods, which has led to the discovery of new resources such as fossil fuels (Stern, 2010).

The economy of any country is energy-dependent, and energy is a limiting factor to economic growth. From this argument, some scholars argue that energy consumption may negatively affect economic growth (Masih \& Masih, 1997; Thoma, 2004). With the aim of analyzing the effect of gas development in the economy, Ahmed and Mttaqah discover a long relationship between gas consumption and real economic growth (Adamu \& Darma, 2016).

Similar to general energy consumption, gas consumption may related to the economig growth direct or indirectly. Fadiran, Adebusuyi and D. Fadiran in 2019 conducted an investigation on Natural gas consumption and economic growth. Using the data from Twelve (12) European countries that are top in the natural gas vehicle market in Europe, and using panel cointegration analysis and vector correction model analysis, they found the existence of the relationship between natural gas consumption and economic and economic growth in the long run. In the short term, it does not exist. In their stud, they used variable gross fixed capital formation, labor force, trade openness, and real GDP (Fadiran, Adebusuyi, \& Fadiran, 2019).

Gafur and Hong (2017) studied dynamics of the natural gas industry and economic growth in Mozambique for the period of 1999 to 2015. They used data from the World Bank and applied the Error correction model to achieve the results. They found that the natural gas industry, export, and labor are positively related to economic growth, and they have a long run. They suggested 
that the Mozambique government should implement a growth policy for the natural gas industry since it would lead to the growth of the economy of Mozambique.

Natural gas production and economic growth are co-integrated and this relation can be seen for a long time of the period. This theory is tested when (Songur, Muratoğlu, \& Muratoğlu, 2016), analyze the relationship between natural gas production and GDP per capital income for five Eurasian countries (Azerbaijan, Russian Federation, Kazakhstan, Turkmenistan, and Uzbekistan). They concluded that energy production plays a significant role in these five economies. The higher the production the higher consumption and therefore, it would be safe to suggest these countries to follow policies, which would increase their natural gas production such as increased infrastructure investments.

In addition to the relation between gas consumption and economic growth, (Mastorakis \& Yazdi, 2014) examined the causality between the two in Iran for a period of 37 years from 1975 to 2011. The study used autoregressive distributed lag and the results show that natural gas consumption has a contribution to domestic production and hence economic growth. More to this (Işik, 2010) examines the role of gas consumption and economic growth in turkey. Using the same method as Mastorakis and Yazdi, the results indicate that natural gas consumption has a positive effect on the economy of Turkish in the short run and has a negative impact in the long run.

The preceding studies examine and analyzed on how energy consumption or gas consumption has an impact on economic growth different method s have been conducted and results have been analyzed. This study aims to provide more literature on how natural gas relates to the economic growth in Tanzania using economic indictors GDP, FDI population and inflation rate.

\section{Research Question}

The aim of the study is to determine the relationship between natural gas consumption and economic growth in Tanzania. The main question is:

Is there any relationship between gas consumption and economic growth in Tanzania?

\section{METHODOLOGY}

Most of the research done can be either qualitative or quantitative. This research is based on qualitative methodology research. In this method, the research is deductive in nature, providing better information that can be relevant in generating the hypothesis (Catherine Scruggs, 2019). Different data and information from the different sources were carefully studied and analyzed in arriving at the conclusion of this study. According to Ghauri and Gronhang (2010), a study outside the natural setting (for our research a country without natural gas resource) would be meaningless. More, a qualitative study is useful for theory development and testing. The aim of this research is to test whether natural gas consumption in Tanzania has any relationship to the country's economy.

\section{Data Collection}

In this research, we aim to establish the impact of gas discovery and production in Tanzania on the country's economy. Data collection is the key element in doing research. In other words, it is the process of gathering and measuring information on targeted variables in an established system, which then enables one to answer relevant questions and evaluate outcomes (Wikipedia, n.d.). Data were collected from the model country thus Tanzania. Most of the data comes from the Ministry of Energy and Tanzania Petroleum Development Company (TPDC). Other information such as economic growth indicators, GDP and inflation rate were also collected from a different source in order to analyses how natural gas production has a related effect on the country's economy.

\section{Data Analysis}

After collection of data is very important to obtain the information of the data collected. This mean knowing the statistic of the data such as means STD median and others. Then before doing the ARDL, the study test for stationarity of the dataset.

\section{Hypothesis of the Study}

The aim of this study is to find out the relation exist between the gasconsumption and economy growth in Tanzania. By using the different economy indicotors, the study will able to find out the relation and give out the recommendetaion. Therefore the hypothesis of this study is:

$\mathrm{H}_{0}=$ Null Hypothesis $=$ Gas consumption has no contribution in Growth of economic in Tanzania.

\section{Auto-Regressive Distributed Lag Approach (ARDL)}

This research paper has opt to use the ARDL because; this model can give out both long and short relationship existence between dependent variable and independent variables. More to the favorite of the model, it can be used regardless of the order of integration as long as the integration does not exceed level 1 of integration (variable became stationary at first difference).

In this study, authors opt to use ARDL in determining the relation between economic growths, natural gas consumption, and another growth indicator. This study will base on the main four indicators; GDP, FDI, Population and inflation rate. ARDL can be presented as:

$$
y_{t}=C+w_{0} x_{t}+w_{1} x_{t-1}+w_{2} x_{t-2}+\ldots+w_{n} x_{t-n}+\text { error term }
$$


Table 2. Summary statistics of the variable from $1995-2018$

\begin{tabular}{|c|c|c|c|c|c|}
\hline Variable & Mean & Median & S.D. & Min & Max \\
\hline $\mathrm{GC}$ & 28.4 & 29.4 & 9.62 & 9.80 & 46.0 \\
\hline GDP & 6.99 & 7.00 & 0.422 & 6.00 & 7.80 \\
\hline Population & 45.1 & 45.0 & 5.03 & 37.4 & 54.2 \\
\hline FDI & $1.28 \mathrm{e}+003$ & $1.30 \mathrm{e}+003$ & 568. & 400. & $2.20 \mathrm{e}+003$ \\
\hline Inflation Rate & 7.64 & 7.03 & 3.60 & 3.51 & 16.0 \\
\hline
\end{tabular}

Source: Author calculation using Eviews

Table 3. Augmented Dickey-Fuller test of stationarity of variables

\begin{tabular}{|c|c|c|c|c|}
\hline \multicolumn{5}{|c|}{ Augmented Dickey-Fuller test statistic } \\
\hline Variable & Tested at: & P - Value & $\mathrm{H}_{\mathrm{o}}$ Status & Result \\
\hline \multirow{2}{*}{ FDI } & Level & 0.4767 & ACCEPT & NON STATIONARY \\
\hline & $\mathrm{D}(\mathrm{FDI})$ & 0.0000 & REJECT & STATIONARY \\
\hline \multirow{2}{*}{ GC } & Level & 0.7779 & ACCEPT & NON STATIONARY \\
\hline & $\mathrm{D}(\mathrm{GC})$ & 0.0007 & REJECT & STATIONARY \\
\hline \multirow{2}{*}{ GDP } & Level & 0.0226 & REJECT & STATIONARY \\
\hline & $\mathrm{D}(\mathrm{GDP})$ & & & \\
\hline \multirow{2}{*}{ Population } & Level & 0.9989 & ACCEPT & NON STATIONARY \\
\hline & $\mathrm{D}$ (Population) & 0.0070 & REJECT & STATIONARY \\
\hline \multirow{2}{*}{ Inflation } & Level & 0.0002 & REJECT & STATIONARY \\
\hline & $\mathrm{D}$ (Inflation) & & & \\
\hline
\end{tabular}

where $y_{t}$ is the value of the dependent variable at time $t, w_{n}$ is lag weight and $x_{t}$ is explanatory variable at time t. ARDL is a model whereby the effect of an independent variable $x$ on dependent variable $y$ occurs with time rather than all at once.

Therefore we estimate the ARDL model using the dependent variable GC and the independence variables and their lags if available. For this study

$$
\begin{aligned}
G C=C+W_{0} G C_{t-1} & +W_{1} G D P_{t-1}+W_{2} F D I_{t-1}+W_{3} I N R_{t-1}+W_{4} P O P_{t-1}+\sum_{i=1}^{p} a 1 G C_{t-1}+\sum_{i=1}^{q 1} a 2 G D P_{t-1}+\sum_{i=1}^{q 2} a 3 F D I_{t-1} \\
& +\sum_{i=1}^{q 3} a 4 I N R_{t-1}+\sum_{i=1}^{q 4} a 5 P O P_{t-1}+e_{t}
\end{aligned}
$$

where by $p$ is the lag length of dependent variable, $q n$ is the lag length of exogeneous variable. $W_{n}$ and an are long run multiplier and shortrun multiplier respectively. $e_{t}$ is white noise error.

Mostly regression models can be used in forecasting different commodities. By doing so they show the significant relationship between a dependent variable and independent variables. More to that it can show the effect change of the dependent variable by the change of independent variable

After the model have been test and relaship have been establish, the stability of test conducted using CUSUM test.

\section{RESULTS AND DISCUSSION}

\section{Data Analysis}

This study employs five variables in testing the relationship that exists between gas consumption and economic growth using four indicators namely GDP, Population FDI, and inflation rate and hence making five variables. Table 2 shows the core general statistic of the variable for the period of $2004-2005$. These are common statistics used.

\section{Unit root test}

Generally, the data given follows the trend of time series data. This means these data varies with time. There are different ways of testing the stability of the data time series, but this study chooses ADF to test the unit root and stationarity of the data. The test was carried out three-time at level up to the first difference. Table 3 gives out the results of the unit root test using ADF. The hypothesis formulates here are:

Null Hypothesis: $\mathrm{H}_{0}$ : variable data has unit root and it is non-stationary

Alternative Hypothesis: $\mathrm{H}_{1}$ : Variable has no unit root and it is stationary.

If the value of probability (P-Value) is greater than $5 \%$, accept the null hypothesis.

\section{Autoregressive Distributed Lag Model}

After determining at what level the data are at stationary, it is important to determine the lags of the model. For the results of our data, there is a mix of data at the stationarity level. Some become stationary at level I (0) and some are stationary after one level I (1). Table 4 shows lag selection based on FPE, AIC, SC, and HQ. the best lag order selection is 1. 
Table 4. Lag selection of the model

\begin{tabular}{|c|c|c|c|c|c|c|}
\hline \multicolumn{7}{|c|}{ VAR Lag Order Selection Criteria } \\
\hline \multicolumn{7}{|c|}{ Endogenous Variable: GC } \\
\hline \multicolumn{7}{|c|}{ Exogenous Variable: C GDP FDI POPULATION INFLATION } \\
\hline Lag & LogL & LR & FPE & $\mathrm{AIC}$ & SC & $\mathrm{HQ}$ \\
\hline 0 & -49.849160 & NA & 37.821040 & 6.452842 & $6.697905^{\star}$ & 6.477202 \\
\hline 1 & -48.713620 & 1.469514 & $37.74060^{\star}$ & $6.436897^{\star}$ & 6.730972 & $6.466129^{\star}$ \\
\hline 2 & -48.600640 & 0.132920 & 42.747650 & 6.541252 & 6.884340 & 6.575356 \\
\hline 3 & -48.480760 & 0.126935 & 48.783540 & 6.644795 & 67.036896 & 6.683771 \\
\hline
\end{tabular}

* indicate lag order selection

LR: Sequential modified LR test at $5 \%$ level

AIC: Akaike information criterion

FPE: Final prediction error

SC: Schwarz information criterion

HQ: Hannan-Quinn information criterion

Table 5. Long-run relationship results using Bound test

\begin{tabular}{|c|c|c|c|c|}
\hline \multicolumn{5}{|c|}{ ARDL Long Run Form and Bound Test } \\
\hline \multicolumn{5}{|c|}{ Dependent Variable: GC } \\
\hline \multicolumn{5}{|c|}{ Levels Equation } \\
\hline \multicolumn{5}{|c|}{ Case 3: Unrestricted Constant and No Trend } \\
\hline \multicolumn{2}{|c|}{ F- Bounds Test } & \multicolumn{3}{|c|}{ Null Hypothesis: No levels relationship } \\
\hline Test Statistic & Value & Signif & $I(0)$ & I(1) \\
\hline \multirow{4}{*}{ F- Statistic } & \multirow{4}{*}{3.113184} & $10 \%$ & 3.03 & 4.06 \\
\hline & & $5 \%$ & 3.47 & 4.57 \\
\hline & & $2.50 \%$ & 3.89 & 5.07 \\
\hline & & $1 \%$ & 4.4 & 5.72 \\
\hline \multicolumn{2}{|c|}{ t- Bounds Test } & \multicolumn{3}{|c|}{ Null Hypothesis: No levels relationship } \\
\hline Test Statistic & Value & Signif & $I(0)$ & $\mathrm{I}(\mathbf{1})$ \\
\hline \multirow{4}{*}{ t- Statistic } & \multirow{4}{*}{2.870936} & $10 \%$ & -3.13 & -4.04 \\
\hline & & $5 \%$ & -3.41 & -4.36 \\
\hline & & $2.50 \%$ & -3.65 & -4.62 \\
\hline & & $1 \%$ & -3.96 & -4.62 \\
\hline
\end{tabular}

Source: Author computed using eviews

After the determination of the lag to be used, the research focus on the long term relationship known as cointegration.

\section{ARDL Cointegration}

Cointegration in economic statistics means long-term relationships among the variables. This can be accomplished by running the cointegration test in various software. This research analysis uses E-views software in analyzing the Cointegration. Nevertheless, our data are not stationary at the same level. Table $\mathbf{3}$ shows some variables are stable at the level and some are stationary after the first difference. It is possible to explain the level of stationary with first differences but ARDL bound testing approach to provide a better solution. (Lee, Kok, Kogid, \& Mulok, 2011) applied the ARDL bounds test without the pre-testing of the variables for unit root tests. Nevertheless, it is rational to perform the unit root tests to ensure the variables are not $I(2)$ or beyond because the bounds test is based on the assumption that the variables are $I(0)$ or $I(1)$. The ARDL bound model, however, can be used for all the cases provided none of the series is beyond I(1) (Pesaran, Shin, \& Smith, 2001) and (Nkoro \& Uko, 2016). This study chooses to test cointegration using ARDL bound test. Table 5 shows the results of the test.

In the ARDL bound test, one can choose to use F-value or T statist value. The criteria are:

Null hypothesis Ho: There is no cointegration between variables.

Alternative hypothesis $\mathrm{H} 1$ : There is cointegration between variables.

If F-value < I (0) accept the Null hypothesis If $F$ - Value > I (1); reject the null hypothesis

For T- statistic value

If T-value < I (0); accept Null hypothesis, If T - value < I (1); Reject Hypothesis

Otherwise, the result is inconclusive and accepts the null hypothesis that there is no Cointegration among variables.

From the analysis in Table 5, there is no long-term relationship between the variable since at 5\% significance level the value of $F$ is less than the value of I (0) thus accepting the null hypothesis, and that makes this study to choose ARDL for the analysis of short-term relationship.

\section{ARDL Analysis}

In this research results it shows $\mathrm{F}$ value of 3.113184 which lies below the value of $\mathrm{I}(0)$ at all levels of significance apart from $10 \%$ significant, and our study is based on $5 \%$ level of significant therefore accept the null hypothesis which state that there is no Cointegration between variables being GC is dependent variable. Thus, indicate there is NO long-term relationship between Gas consumption and variables GDP, FDI, population and interest rate. In simple terms, it indicates there is no long-run relationship between gas consumption and the economic growth in Tanzania. 


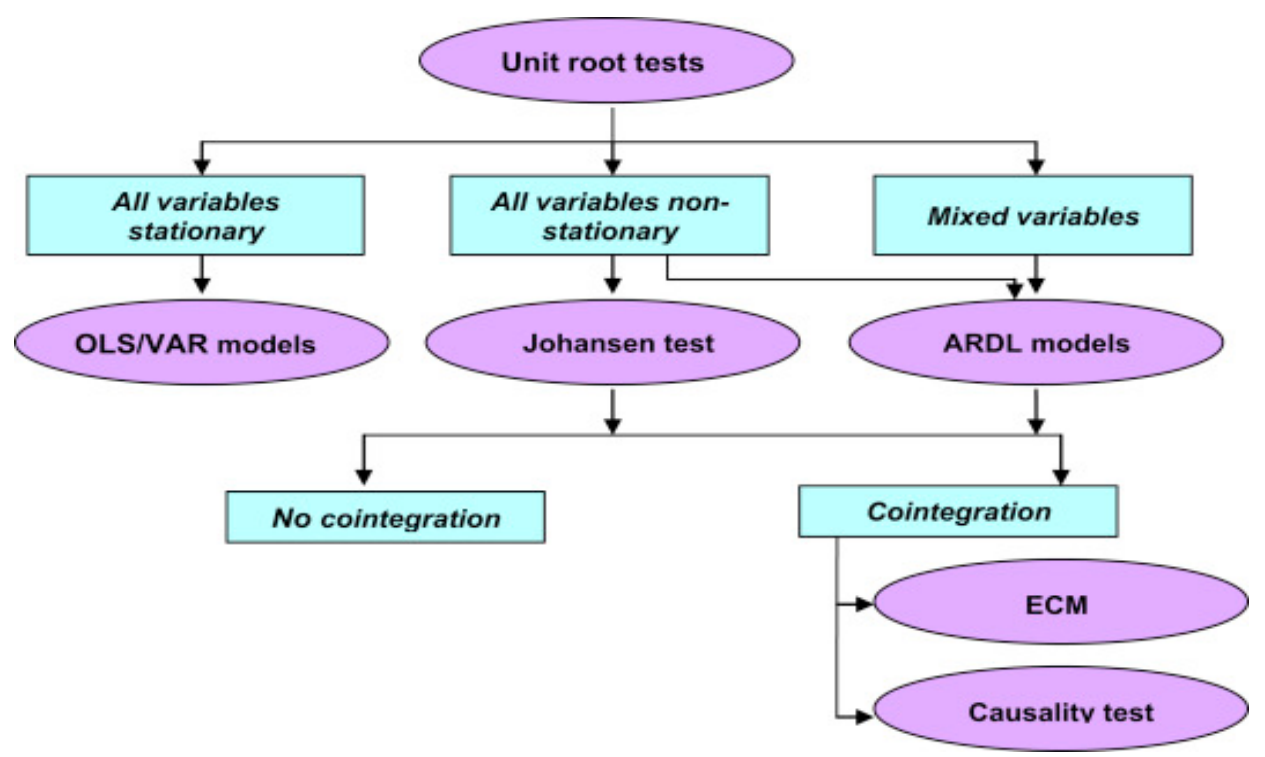

Figure 1. Method selection for time series data (Shrestha \& Bhatta, 2018)

Table 6. Serial correlation of the variable

\begin{tabular}{|c|c|c|c|c|}
\hline \multicolumn{5}{|c|}{ Breusch-Godfrey Serial Correlation LM Test } \\
\hline \multicolumn{5}{|c|}{ Null hypothesis: No Serial correlation at up to 1 lag } \\
\hline F statistic & 0.146822 & \multicolumn{2}{|c|}{ Prob $F(1,15)$} & 0.707 \\
\hline Obs* R-squared & 0.232638 & \multicolumn{2}{|c|}{ Prob chi-square (1) } & 0.6296 \\
\hline \multicolumn{5}{|c|}{ Dependent Variable: GC } \\
\hline \multicolumn{5}{|c|}{ Method: ARDL } \\
\hline \multicolumn{5}{|c|}{ Maximum dependent lag: 1 (Automatic selection) } \\
\hline \multicolumn{5}{|c|}{ Model Selection Method: Akaike info Criterion (AIC) } \\
\hline \multicolumn{5}{|c|}{ Selected model: ARDL $(1,1,1,0,0)$} \\
\hline Variable & Coefficient & Std Error & t-Statistic & Prob. $^{*}$ \\
\hline $\mathrm{GC}(-1)$ & 0.226310 & 0.224941 & 1.006083 & 0.3293 \\
\hline GDP & 1.138873 & 1.604082 & 0.709984 & 0.4879 \\
\hline GDP(-1) & 1.833719 & 1.297153 & 1.413649 & 0.1766 \\
\hline FDI & 0.004671 & 0.003418 & 1.366648 & 0.1906 \\
\hline FDI(-1) & 0.004136 & 0.003244 & 1.274984 & 0.2205 \\
\hline POPULATION & 0.656801 & 0.392605 & 1.672930 & 0.1138 \\
\hline INFLATION & 0.674796 & 0.248286 & 2.717812 & 0.0152 \\
\hline $\mathrm{C}$ & -44.70908 & 15.64296 & -2.858096 & 0.0114 \\
\hline R-square & 0.953026 & \multicolumn{2}{|c|}{ Mean dependent var } & 17.7466 \\
\hline Adjusted R-square & 0.932475 & \multicolumn{2}{|c|}{ S.D dependent var } & 15.9226 \\
\hline S.E of regression & 4.137563 & \multicolumn{2}{|c|}{ Akaike info criterion } & 5.9393 \\
\hline Sum squared resid & 273.9109 & \multicolumn{2}{|c|}{ Schwarz criterion } & 6.3320 \\
\hline Log likelihood & -63.27151 & \multicolumn{2}{|c|}{ Hannan-Quinn criter. } & 6.0435 \\
\hline F-statistic & 46.37387 & \multicolumn{2}{|c|}{ Durbin-Watson stat } & 2.1241 \\
\hline Prob (F-statistic) & 0.000000 & & & \\
\hline
\end{tabular}

Source author computation

Because there is no long relationship between the variable, the research considers the ARDL to capture the existence of shortrun relation if it does exist. Figure 1 explains more about the ARDL model. According to (Shrestha \& Bhatta, 2018), when there is no Cointegration just Perform the short-run relation analysis. Shrestha \& Bhatta (2018) explained that if there is no long-run relationship between the variable, it better to run the ARDL model to obtain the short term relation. Figure 1 shows how the Shrestha and Bhatta meant. The study estimates the short term relationship of the variable using the ARDL method.

Because we have shown no Cointegration between that variable, the study will run the ARDL and test for serial correlation and stability of the model. Table 6 shows the results of the ARDL model. The results show that the model is healthier by $95.3 \%$ as Rsquares shows. More to that the model shows to be significant by look the value of $t$-statistic. The value of the $t$-statistic should be more than 1.5. Nevertheless, FDI shows less, equivalent to no short relation to the dependent variable (gas consumption). It is important to check if there are serial correlation and the stability of the model.

\section{Correlation and Causality}

The correlations matrix below provides the opportunity to assess the degree of multicollinearity between the variables of the model before the regression analysis (Sylvester, Benedict, \& Kingsley, 2015). In Table 8, the first row (after heading) explains the 
Table 7. Correlation of variables

\begin{tabular}{ccccc}
\hline GC & GDP & Population & FDI & Inflation \\
\hline 1 & 0.63891 & 0.9083 & 0.8936 & -0.3105 \\
\hline 1 & 0.7248 & 0.6299 & -0.8042 & -0.5211 \\
\hline & & 1 & 0.8140 & -0.3599 \\
\hline
\end{tabular}

Source author computation

Table 8. Relationship of the variable using granger causality test

\begin{tabular}{|c|c|c|c|c|}
\hline \multicolumn{5}{|c|}{ Pairwise Granger Causality Tests } \\
\hline Null Hypothesis & Obs & F-Statistic & Prob & Selection \\
\hline GC does not Granger Causes FDI & \multirow{2}{*}{24} & 8.23350 & 0.0092 & REJECT \\
\hline FDI does not Granger Causes GC & & 2.24433 & 0.1490 & ACCEPT \\
\hline GDP does not Granger Causes FDI & \multirow{2}{*}{24} & 0.19184 & 0.6659 & ACCEPT \\
\hline FDI does not Granger Causes GDP & & 0.00122 & 0.9725 & ACCEPT \\
\hline INFLATION does not Granger Causes FDI & \multirow{2}{*}{24} & 0.07351 & 0.7889 & ACCEPT \\
\hline FDI does not Granger Causes INFLATION & & 0.08811 & 0.7695 & ACCEPT \\
\hline POPULATION does not Granger Causes FDI & \multirow{2}{*}{24} & 2.57677 & 0.1234 & ACCEPT \\
\hline FDI does not Granger Causes POPULATION & & 0.04169 & 0.8402 & ACCEPT \\
\hline GDP does not Granger Causes GC & \multirow{2}{*}{24} & 3.45255 & 0.0772 & ACCEPT \\
\hline GC does not Granger Causes GDP & & 0.18368 & 0.6726 & ACCEPT \\
\hline INFLATION does not Granger Causes GC & \multirow{2}{*}{24} & 1.02018 & 0.3240 & ACCEPT \\
\hline GC does not Granger Causes INFLATION & & 0.26210 & 0.6140 & ACCEPT \\
\hline POPULATION does not Granger Causes GC & \multirow{2}{*}{24} & 2.40084 & 0.1362 & ACCEPT \\
\hline GC does not Granger Causes POPULATION & & 1.59890 & 0.2199 & ACCEPT \\
\hline INFLATION does not Granger Causes GDP & \multirow{2}{*}{24} & 0.68451 & 0.4173 & ACCEPT \\
\hline GDP does not Granger Causes INFLATION & & 1.34835 & 0.2586 & ACCEPT \\
\hline POPULATION does not Granger Causes GDP & \multirow{2}{*}{24} & 0.71368 & 0.4077 & ACCEPT \\
\hline GDP does not Granger Causes POPULATION & & 0.11775 & 0.7349 & ACCEPT \\
\hline POPULATION does not Granger Causes INFLATION & \multirow{2}{*}{24} & 0.10787 & 0.7458 & ACCEPT \\
\hline INFLATION does not Granger Causes POPULATION & & 0.36019 & 0.5548 & ACCEPT \\
\hline
\end{tabular}

\section{Source author}

correlation between dependent variable, in our case gas consumption and other independent variables. Other rows show how the independent variable correlate to each other.

Causality test the relation of the variable and the direction of the relationship among the variable. This research study conducts causality and sees the direction of the relationship. Table 8 shows the results of the test. There is only one cause-effect relationship between gas consumption and FDI and it is one direction. That means Gas consumption can cause an effect on FDI. Here accept the null hypothesis if $\mathrm{P}$-value us greater than $5 \%$.

\section{Stability of the Model}

The stability of the model is testing using CUSUM. CUSUM is a cumulative sum control chart. The chart is based on the cumulative sum together with the $5 \%$ significance level. If the chart goes beyond this level, the variables are unstable. According to (Brown, Durbin, \& Evans, 1975), the test finds parameter instability if the cumulative sum goes outside the area between the two critical lines. Figure 2 shows the stability of the model.

\section{CONCLUSION}

This research study concentrates on investigating the relationship between natural gas consumption and economic growth in Tanzania. The investigation covers a period of 25 years from 1994 to2018. The study used ARDL as the method to identify the causality and the long relationship between the gas consumption variable and economic growth variables (GDP, FDI, population, and Inflation rate). From the analysis above, it has indicated that there is no long-run relationship between natural gas consumption and Economic growth. More to that the study explores the causality of the variable. Only Granger effect was found on gas consumption on FDI. No other granger effect was found in any variable. This means the Gas consumption can have an effect on FDI, but not FDI causing the effect on gas consumption.

For the short run, the result did satisfy the t-statistic at 5\% significant level. However, the correction among variable can show how each variable correlate with other one. Therefore, the study accepts the Null hypothesis which state that Gas consumption has no contribution in Economic growth.

Also, casuality was found only in one direction from gas consumption to the FDI. This indicates that the consumption of gas casuse the effect on the FDI. As FDI is one of the sources of heavy investment within the country, it will lead big project in the country and hence bossting economy. 


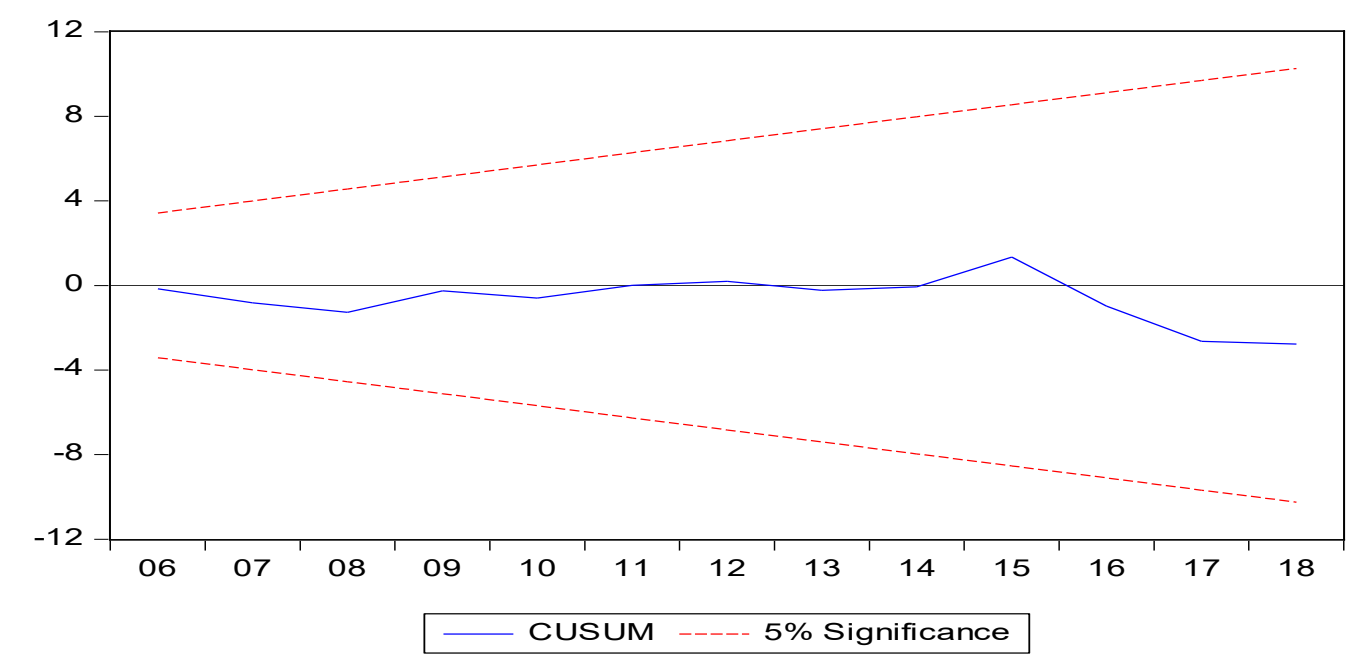

Figure 2. Stability of the model using Cusum

Ontop of that, many studies have suggested, there is relation between energy and economic growth (Stambuli, 2014), but still there is a debate if energy lead to economic growth or economic growth lead to energy consumption. This study be a motivation to more researchers to conduct and analyses the relationship between any mean of energy and the economic growth in any country.

From year 2016, Tanzania emphasizes on using gas in production of electric power. This may lead to the reliable and stable availability of electric power within the country and hence will attract more investor to invest in Tanzania. This also guarantee promotion of economic energy. Therefore, the Government should put into action the policy that will enable the Tanzania to benefit from the available gas and improve the living standard of her citizen and the economic growth of country.

\section{REFERENCES}

Adamu, A., \& Darma, R. (2016). Inland Natural Gas Consumption and Real Economic Growth in Nigeria: ARDL Cointegration Test. Journal of Economics and Sustainable Development, 7(8), 2222-1700. Retrieved from www.iiste.org

Akinlo, A. E. (2012). How Important is Oil in Nigeria's Economic Growth? Journal of Sustainable Development, 5(4). https://doi.org/10.5539/jsd.v5n4p165

Al-khawaldeh, M., \& Al-qudah, A. M. (2018). The Effect of Energy Consumption on Economic Growth in Jordan. International Journal of Academic Research in Accounting, Finance and Management Sciences, 8(2), 170-177. https://doi.org/10.6007/IJARAFMS/v8i2/3782

Apergis, N., \& Payne, J. E. (2010). Natural gas consumption and economic growth: A panel investigation of 67 countries. Applied Energy, 87(8), 2759-2763. https://doi.org/10.1016/J.APENERGY.2010.01.002

Brown, R. L., Durbin, J., \& Evans, J. M. (1975). Techniques for Testing the Constancy of Regression Relationships over Time. Journal of the Royal Statistical Society. Series B (Methodological), 37, 149-192. https://doi.org/10.2307/2984889

Fadiran, G., Adebusuyi, A. T., \& Fadiran, D. (2019). Natural gas consumption and economic growth: Evidence from selected natural gas vehicle markets in Europe. Energy, 169, 467-477. https://doi.org/10.1016/j.energy.2018.12.040

Gafur, N. B., \& Hong, L. (2017). Dynamics of the Natural Gas Industry and Economic Growth in Mozambique. Science Journal of Energy Engineering, 5(3), 68. https://doi.org/10.11648/j.sjee.20170503.13

Hassan, M. S., Tahir, M. N., Wajid, A., \& Mahmood, H. (2017). Natural Gas Consumption and Economic Growth in Pakistan: Natural Gas Consumption and Economic Growth in Pakistan: Production Function Approach. Global Business Review, (August 2018). https://doi.org/10.1177/0972150917713533

Işik, C. (2010). Natural gas consumption and economic growth in Turkey: A bound test approach. Energy Systems, 1(4), $441-456$. https://doi.org/10.1007/s12667-010-0018-1

Kahyoza, N. (2013). Tanzania Gas Sector Economy in the Light of Human Development.

Lee, S., Kok, S. C., Kogid, M., \& Mulok, D. (2011). Empirical Analysis of Employment and Foreign Direct Investment in Malaysia: An ARDL Bounds Testing Approach to Cointegration. Advances in Management \& Applied Economics, (January).

Masih, A. M. M., \& Masih, R. (1997). On the temporal causal relationship between energy consumption, real income, and prices: Some new evidence from Asian-energy dependent NICs Based on a multivariate cointegration/vector error-correction approach. Journal of Policy Modeling, 19(4), 417-440. https://doi.org/10.1016/S0161-8938(96)00063-4

Mastorakis, N., \& YAZDI, S. (2014). Natural gas consumption and economic growth in Iran. Advances in Environmental Technology and Biotechnology. Retrieved from https://www.researchgate.net/publication/308748423_Natural_gas_consumption_and_ economic_growth_in_Iran 
Nkoro, E., \& Uko, A. K. (2016). Autoregressive Distributed Lag (ARDL) cointegration technique: application and interpretation. Journal of Statistical and Econometric Methods, 5(4), 63-91.

Pesaran, M. H., Shin, Y., \& Smith, R. J. (2001). Bounds testing approaches to the analysis of level relationships. Journal of Applied Econometrics, 16(3), 289-326. https://doi.org/10.1002/jae.616

Rosser, A. (2006). The Political Economy of the Resource Curse: A Literature Survey. Working Paper Series, 268.

Sankaran, A., Kumar, S., K, A., \& Das, M. (2019). Estimating the causal relationship between electricity consumption and industrial output: ARDL bounds and Toda-Yamamoto approaches for ten late industrialized countries. Heliyon, 5(6), e01904. https://doi.org/10.1016/J.HELIYON.2019.E01904

Shahbaz, M., Arouri, M., \& Teulon, F. (2014). Short- and long-run relationships between natural gas consumption and economic growth: Evidence from Pakistan. Economic Modelling, 41, 219-226. https://doi.org/10.1016/J.ECONMOD.2014.05.019

Shrestha, M. B., \& Bhatta, G. R. (2018). Selecting appropriate methodological framework for time series data analysis. The Journal of Finance and Data Science, 4(2), 71-89. https://doi.org/10.1016/J.JFDS.2017.11.001

Songur, M., Muratoğlu, G., \& Muratoğlu, Y. (2016). Natural Gas Production and Economic Growth in Eurasian Countries: Evidence from a Panel ARDL Model. Bulletin of Energy Economics, 4(2)(January), 155-162.

Stambuli, B. B. (2014). Oil Consumption and Economic Growth Nexus in Tanzania Co integration and Causality Analysis. International Journal of Academic Research in Economics and Management Sciences, 3(2), 113-123. https://doi.org/10.6007/IJAREMS/v3-i2/769

Stern, D. (2010). The Role of Energy in Economic Growth. Crawford School Centre for Climate Economics \& Policy Paper No. 3.10, (October).

Sylvester, A., Benedict, A., \& Kingsley, I. (2015). A VAR Analysis of the Relationship between Energy Consumption and Economic Growth in Nigeria. Journal of Economics and Sustainable Development, 6(12), 1-13.

Thoma, M. (2004). Electrical energy usage over the business cycle. Energy Economics, 26(3), 463-485. https://doi.org/10.1016/J.ENECO.2004.04.006 